\title{
Short-term successional dynamics of a macroalgal community in a stream from northwestern São Paulo State, Brazil
}

\author{
Fábio Renato Borges ${ }^{1}$ and Orlando Necchi Júnior ${ }^{1,2}$
}

Received: June 6, 2006. Accepted: July 2, 2007

\begin{abstract}
RESUMO - (Dinâmica sucessional em curto período da comunidade de macroalgas em um riacho da região noroeste do Estado de São Paulo, Brasil). Este estudo visou: descrever um evento de sucessão ecológica em curto período (70 dias) da comunidade de macroalgas após distúrbio artificial (remoção); avaliar se as características da estrutura da comunidade foram semelhantes antes e depois do período experimental; comparar o processo sucessional em dois trechos experimentais (parcialmente e totalmente perturbados, TPP e TTP), simulando distúrbios de médio (parcial) e grande impacto (completa remoção). Com relação ao tempo de colonização, Oedogonium sp. foi classificada como sucessional indiferente, enquanto Chaetophora elegans (Roth) C. Agarth e Batrachospermum delicatulum (Skuja) Necchi et Entwisle como sucessionais tardias para TTP; para TPP a única diferença foi que Oedogonium sp. foi classificada como sucessional tardia. Temperatura foi a variável mais influente para a maioria das espécies e variáveis biológicas, com aumentos de temperatura provavelmente favorecendo taxas de reprodução. Quanto à estratégia de vida Oedogonium sp. foi classificada como estrategista C-S, enquanto B. delicatulum e C. elegans como estrategistas S para os dois trechos. De maneira geral, a recuperação da estrutura da comunidade não foi completa ao final do período de sucessão. Este estudo de curto período foi consistente com o processo de sucessão determinístico, pois a trajetória de sucessão foi previsível, porque riqueza e abundância de espécies, formas de crescimento e estratégias de vida seguiram um padrão definido.
\end{abstract}

Palavras-chave: estratégia de vida, ecossistema lótico, macroalga, sucessão

\begin{abstract}
Short-term successional dynamics of a macroalgal community in a stream from northwestern São Paulo State, Brazil). This investigation aimed to describe a short term (70 days) ecological succession event of a macroalgal community in a stream from northwestern São Paulo state (20 43'S; $49^{\circ} 13^{\prime} \mathrm{W}$ ) after artificial disturbance (removal); evaluate if community structure characteristics were similar before and after the experimental period; compare the successional process of two experimental stream segments (partly and completely disturbed segments, PDS and CDS, respectively), simulating medium (partial) and high impact (complete removal) disturbances. In terms of colonization time, Oedogonium sp. was classified as successionally indifferent, whereas Chaetophora elegans (Roth) C. Agarth and Batrachospermum delicatulum (Skuja) Necchi et Entwisle were classified as late successional forms for CDS; for PDS the only difference was that Oedogonium sp. was classified as late successional. In terms of successional strategy, Oedogonium sp. was classified as a C-S strategist, whereas C. elegans and B. delicatulum were regarded as S strategists for both stream segments. Temperature was the most influential variable for most species and biological variables, with temperature increases probably favouring reproduction rates. In general, community structure recovery was not complete at the end of succession. This short-term study was consistent with the deterministic process of succession, since the succession trajectory was predictable, because species richness and abundance, growth forms and life strategies followed a definite pattern.
\end{abstract}

Key words: life strategy, lotic ecosystem, macroalgae, succession

\section{Introduction}

Succession is the process that animal and plant communities undergo leading to a final stage (climax), which is usually recognized by its stability and clear environmental relationship in a regional scale (Dawson et al. 1978). Although succession is a core subject in Ecology, it is definitely a difficult topic to approach (McIntosh 1974). Connell \& Slatyer's (1977) model is one of the best known theoretical systems for the study of the succession process. According to those authors, the succession mechanisms can be incorporated in three models: 1) facilitation, that corresponds to the Clementesian model of floristic substitution (Egler 1954), in which early successional species modify the environment and facilitate the appearance of late successional species; 2) inhibition, which states that the initial invaders (Egler 1954), regulate the succession

\footnotetext{
${ }^{1}$ Universidade Estadual Paulista, Departamento de Zoologia e Botânica, Rua Cristóvão Colombo 2265, 15054-000 São José do Rio Preto, SP, Brasil

2 Corresponding Author: orlando@ibilce.unesp.br
} 
in such a way that the late successional species cannot invade and grow in the presence of healthy early successional species; 3) tolerance, in which floristic changes can occurred as a function of attributes of life history and distinct abilities of late successional species in tolerating the initial environmental conditions. Connell \& Slatyer's model has been used in experimental, as well as in descriptive studies (e.g. several examples cited by Pickett et al. 1987), although the latter authors have pointed some limitations to its application.

According to Biggs et al. (1998) the physical environment is the filter to the development of specific characteristics during the evolution time, which can be better analyzed and understood by separating the environment in different combinations imposed by the primary and secondary variables (frequency of disturbance events and resource supplies, respectively). They also stated that the different periphytic taxa have developed specialized characteristics that enable them to explore one or several sectors of a habitat matrix. In addition, any levels of changes in the disturbance frequency or nutrient supplies (or both) can result in a displacement of the dominance inside the community. They proposed a habitat matrix conceptual model based on the C-R-S system proposed by Grime $(1977 ; 1979)$ and on the dynamic equilibrium theory of Huston (1979; 1994). The model was used to classify 35 taxa of periphyton according to their life strategies. According to this system, species life strategies were divided into four different kinds: competitive strategy (C), represented by species that are able to grow well in habitats stable and rich in nutrients (eutrophic); strategy $\mathrm{C}-\mathrm{S}$, with species more adapted to stable habitats and moderate nutrient concentrations (mesotrophic); stresstolerant strategy $(\mathrm{S})$, that involves species well adapted to stable habitats, but with low nutrient concentrations (oligotrophic); and the ruderal strategy (R), including species that are adapted to environments moderately or highly disturbed and with variable nutrient supply.

Investigations on algal succession have usually been restricted to the study of the seasonal changes in species composition, which are mostly derived from predictable environmental changes during the year (McCormick \& Stevenson 1991). Some studies have demonstrated the importance of single environmental variables in the succession process. Peterson \& Stevenson (1992) analyzed the importance of current velocity to the species resistance and resiliency during the sucessional process. Dudley \& D'Antonio (1991) reported the effects of substratum texture, herbivory and disturbance (current velocity increase) on macroalgal stablishment. McCormick \& Stevenson (1991) described the action of current velocity, among other factors, in the classification of the dominant species as early or late sucessionals. Steinman et al. (1991) analyzed the patterns of recolonization in lotic ecosystems following a light elimination disturbance.

The seasonal patterns of macroalgal communities have been described for some drainage basins in the northwest region of Sno Paulo State (Necchi Jr. \& Pascoaloto 1993; Branco \& Necchi Jr. 1997). They are typically characterized by two distinct periods, essentially determined by the rainfal regime and related to current velocity, irradiance, turbidity and depth: the dry season, extending from May to October, with higher macroalgal species richness and abundance; and the rainy season, from November to April with lower species richness and abundance. These could be considered as "annual succession events". A general finding is that there are no major changes in the composition of macroalgal communities of the same river segment in consecutive years, except in atypical years or in particular cases. On the basis of this premise, our initial hypothesis is that the community structure characteristics (species composition, richness and diversity), observed at the beginning of the successional experiment will tend to be reestablished at the end of the period. The only successional study on stream macroalgae in Brazil was made by Branco et al. (2005). They described the successional changes of some community characteristics during one year, as well as the role of some environmental variables, immediately after the occurrence of a strong disturbance event (flood).

Considering the scarcity of information on succession dynamics of macroalgal communities in tropical regions, this study was carried out aiming to: 1) describe a short-term (70 days) ecological succession event for a macroalgal community after artificial disturbance (removal) in a stream from the northwest region of Sno Paulo; 2) evaluate if the community structure characteristics (species composition, richness, abundance and diversity) were similar at the initial and final stages of the experimental period; 3) compare the dynamics of the sucessional process between two experimental stream segments (partially and completely disturbed).

\section{Materials and methods}

The successional experiment was carried out in a second-order stream (Talhadinho), belonging to the 
Preto River drainage basin, located at the municipality of São José do Rio Preto, Route SJR-351, District of Talhado (20 $43^{\circ}$ 'S and $\left.49^{\circ} 13^{\prime} \mathrm{W}\right)$. Field experiment was conducted from July 31 to October 10, 2004, within the typical period of higher macroalgal species richness and abundance in this region (Necchi Jr. \& Pascoaloto 1993; Branco \& Necchi Jr. 1997). The stream segment has an artificial substratum (concrete), since it is located close to a bridge, and is open (well illuminated) with a dominantly herbaceous (sparsely shruby) marginal vegetation. This stream was chosen because of its favorable physical characteristics to the aims of this study, as well as for having been relatively well-studied previously as to macroalgal seasonal dynamics (Necchi Jr. \& Pascoaloto 1993; Necchi Jr. \& Branco 1999; Branco \& Necchi Jr. 2003).

For the successional experiment the stream segment was divided in two halves in relation to the width using an already existing division from the bridge support column (Fig. 1). Each half consisted of a 5 meter length and 2.5 meter width segment. For macroalgal sampling, we applied the quadrat technique, combined to the point-intercept method (Krebs 1989; Necchi Jr. et al. 1995; Necchi Jr. 2004), for evaluation of macroalgal percent cover (by visual estimate). In each 1 meter segment along the stream length two sampling units were placed on the stream bottom. Sampling units consisted of circles with $25 \mathrm{~cm}$ in diameter $\left(491 \mathrm{~cm}^{2}\right.$ of area) positioned side by side and distant 1 meter from each other, totalizing 10 units within each area (Fig. 1). In both stream segments an initial sampling was made (before initiating the experiment) for evaluation of original characteristics of the macroalgal community (richness, abundance and diversity), as well as the physical variables (current velocity, irradiance and depth), to provide a basis for comparison with results throughout the experimental period.

After the initial sampling, each stream segment was subjected to a different treatment aiming compare the successional dynamics (variation of environmental and biological conditions) under different disturbance degrees (total and partial elimination of the communities). One of the stream segments (Fig. 1), called completely disturbed segment (CDS) had a full removal (by scratching and brushing) of the community. The other stream segment, called partially disturbed segment (PDS), the community removal (by the same methods) was made only for the areas of the sampling units $(25 \mathrm{~cm}$ in diameter), with an additional area of $10 \mathrm{~cm}$ around them (Fig. 1). The remaining area of the community was kept intact. For a precise location of the sampling units along the experimental period, landmarks were made on the bottom, as well as in the stream margins for both stream segments. In addition, a schematic drawing (similar to that depicted on Fig. 1) was brought to the field in all sampling dates.

Previous data (Necchi Jr. \& Pascoaloto 1993; Branco \& Necchi Jr. 1997) indicated that tropical lotic macroalgal colonization can change rapidly (weekly). Accordingly, sampling was conducted in weekly intervals, minimizing the chances of missing important events along the experimental period. A preliminary test was made during the period of August 22 to November 14, 2002, consisting of five samplings with intervals of 7, 14 and 30 days. This test provided relevant information for a proper estimation of the sampling frequency, as well as the length of the experiment. The end of the experimental period was determined by the occurrence of the first intense rainfal event, evaluated by its effects on macroalgal abundance, provoking a break to the successional process. Rainfal data were obtained from C.A.T.I. (Coordenadoria of Integral Technical Assistance) of the state Agriculture Secretariat from São Paulo, for the nearest locality (Talhado District).

In each sampling date, a collection of five samples of living material was made for determination of macroalgal biomass (dry weight and chlorophyll $a$ ) at CDS, with the purpose of providing additional data of community's succession. Sampling units for biomass estimate consisted of circles with $10 \mathrm{~cm}$ in diameter

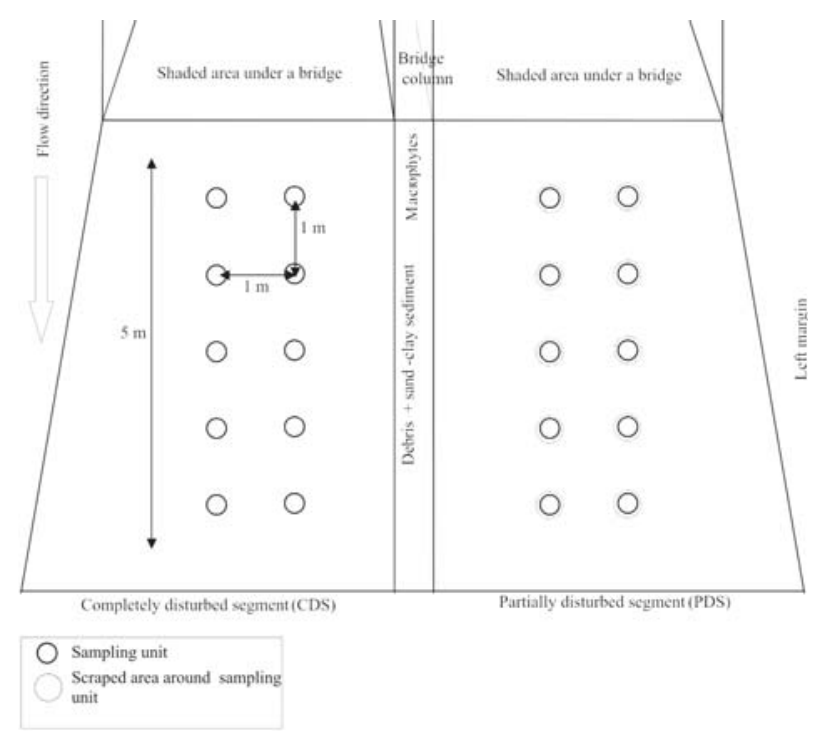

Figure 1. Schematic representation of the sampling design at the sampling site showing the position of sampling units within the two experimental segments: completely and partially disturbed. 
( $78.5 \mathrm{~cm}^{2}$ of area), inside of which the substratum was fully scraped and its content transfered to vials. This material was carried to the laboratory, cleaned from debris and materials other than macroalgae (e.g. briophytes). The collection of such samples within CDS was made randomly, according to the procedure described by Necchi Jr. (1997). The position (coordinates within the sampling segment) of each area was annotated to avoid recollections within the same areas. The evaluation of dry weight and chlorophyll $a$ were made by gravimetric and spectrophotometric techniques, respectively (APHA 1992).

Besides the physical data analyzed within each sampling unit, the following environmental variables were measured in each for the whole stream segment: temperature, $\mathrm{pH}$, turbidity, conductivity and dissolved oxygen were measured with a Horiba U-10 water quality checker, equiped with multiple function probe from three water samples collected during the sampling period (from 11:00 and 12:00 h). Inorganic nutrients (ammonium, nitrate and orthophosfate) were also analyzed in laboratory with a Merck SQ 118 spectrophotometer and Spectroquant reagents specific for each nutrient from water samples kept frozen $(<30$ days).

Pearson's correlation coefficient (Zar 1999) was applied to the data (colonization time and percent cover) aiming to determine the successional status of each species. Results were interpreted as follows (as described by McCormick \& Stevenson 1991): if percent cover was negatively correlated with time, the species was classified as early sucessional (pioneer); if cover was not correlated with time, the species was classified as indifferent sucessional; if cover was positively correlated with time, the species was classified as late sucessional. Pearson's coefficient was also calculated among environmental variables and other biological variables (percent cover of indivual species, biomass - dry weight and chlorophyll, ShanonWiener diversity index and species richness). Multiple regression analysis (Zar 1999) was applied to evaluate the relationship of a set of variables with biological variables. Student's $t$ test (Zar 1999) was used to test for significant differences for values of environmental variables between CDS and PDS. One way analysis of variance (ANOVA, Zar 1999) was applied to test for significant differences among values of physical and biological variables among sampling dates. When significant differences were found Newman-Keuls multiple comparison test (Zar 1999) was applied to evaluate the significantly different values inside the set.
All statistical tests were performed using the Statsoft Statistica package, version 5.5, whereas the graphs were prepared with Microcal Origin software, version 5.0.

\section{Results}

Environmental variables - Depth was significantly higher at PDS $(7.1 \pm 0.4 \mathrm{~cm}$, mean \pm standarddeviation), in comparison to CDS $(5.7 \pm 0.5 \mathrm{~cm})$ on all samplind dates, except the last one (Fig. 2). Irradiance was higher at CDS $\left(1690 \pm 688 \mu \mathrm{mol} \cdot \mathrm{m}^{2} . \mathrm{s}^{-1}\right)$ thant at PDS $\left(1516 \pm 648 \mu \mathrm{mol} . \mathrm{m}^{2} . \mathrm{s}^{-1}\right)$ but not significant different. The low values observed on days 8 and 70 were due to cloudy conditions. Current velocity was similar at both stream segments $(47.8 \pm 5.7$ and $45.6 \pm$ $7.6 \mathrm{~cm} \cdot \mathrm{s}^{-1}$ at CDS and PDS, respectively). It is interesting to notice a slight increase (not significant) in current velocity measured before the experiment and after removal of the macroalgal community from 38.0 to $43.9 \mathrm{~cm} . \mathrm{s}^{-1}$ at CDS and from 40 to $43 \mathrm{~cm} \cdot \mathrm{s}^{-1}$ at PDS (Fig. 2).

With regard to other environmental variables measured for the entire stream segment, we observed a gradual increase (with oscillations) in values of temperature, conductivity and $\mathrm{pH}$ (Fig. 3), the latter with the most defined pattern. Temperature was positively correlated with time $(r=0.79, \mathrm{p}<0.05)$ and negatively with ammonium concentration $(\mathrm{r}=-0.75$, $\mathrm{p}<0.05)$. Turbidity $(27.7 \pm 10.1 \mathrm{NTU})$ and dissolved oxygen $\left(5.1 \pm 0.5 \mathrm{mg} . \mathrm{L}^{-1}\right)$ fluctuated widely along the experimental period (Fig. 3).

Nitrate $\left(0.38 \pm 0.19 \mathrm{mg} . \mathrm{L}^{-1}\right)$ and ammonium $\left(0.09 \pm 0.02 \mathrm{mg} . \mathrm{L}^{-1}\right)$ concentrations were negatively correlated $(r=-0.67, p<0.05)$, the former tended to increase (positive correlation with time), whereas the latter to decrease along the experiment (Fig. 3), with positive $(r=0.77, p<0.05)$ and negative $(r=-0,80$, $\mathrm{p}<0.05)$ correlation with time, respectively. Nitrate concentrations were higher than those of ammonium throughout the period, except on days 7 and 14 . Ortophosfate $\left(0.06 \pm 0.02 \mathrm{mg} . \mathrm{L}^{-1}\right)$ had a steady concentration during the experiment, with a considerable increase just on the last day (Fig. 3). Orthofosfate and nitrate were positively correlated $(\mathrm{r}=075, \mathrm{p}<0.05)$.

General sucessional process - During the sucessional process at CDS we found three macroalgal species and one moss. The appearance sequence was: 1) Fissidens sp. (moss) and Oedogonium sp.; 2) Chaetophora elegans (Roth) C. Agardh and 

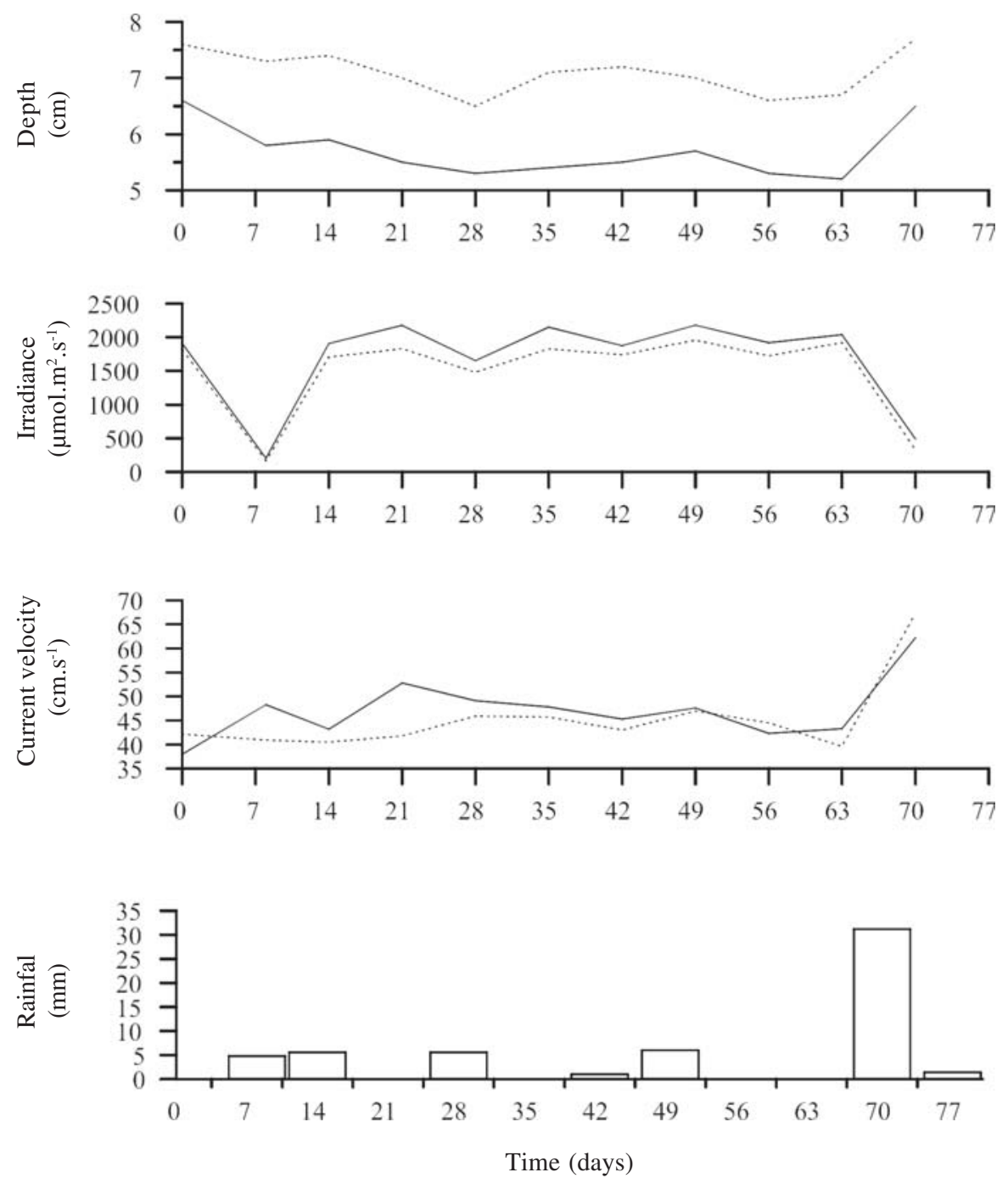

Figure 2. Dynamics of physical variables and rainfall during the study period (July 31 to October 10, 2004) at the two experimental segments of the sampling site: completely and partially disturbed. (- - Completely disturbed segment - CDS; ..... - Partially disturbed segment - PDS).

3) Batrachosperum delicatulum (Skuja) Necchi et Entwisle. PDS had the same species, plus the cyanophyte Phormidium retzii (C. Agardh) Gomont, that was observed once (day 21) in one of the sampling units with a low cover (1\%). The species appearance order was the same as for CDS, except that $P$. retzii appeared before $C$. elegans.

Total percent cover at the end of the experiment did not reach the values observed before the event of artificial disturbance in none of the two stream segments (Fig. 4-5). We found that for Recolonization speed and the peak of total cover were significantly higher at CDS $(t=3.95, \mathrm{p}<0.05)$ than at PDS (peak of $44.8 \%$ in the $49^{\text {th }}$ day for and of $19.3 \%$ in the $70^{\text {th }}$ day, respectively, Fig. 4-5). In contrast, total cover significantly decreased at the end of the experiment for CDS, whereas for PDS there was still a small increase. Shanon-Wiener diversity index was higher at the end $\left(\mathrm{H}^{\prime}=0.58\right.$ for CDS and $H^{\prime}=0.34$ for PDS) than before the disturbance $\left(H^{\prime}=0.58 \times 0.38\right.$ for $C D S$ and $H^{\prime}=0.34 \times 0.30$ for PDS, Fig. 4). As a rule, values were relatively low and variable up to $28^{\text {th }}$ and $35^{\text {th }}$ days and increased steadly thereafter. Species richness was reduced immediately after the disturbance and reached the same initial value at the end of the experiment for both stream segments (Fig. 4). Species richness peak was reached one week earlier at CDS than at PDS (49 ${ }^{\text {th }}$ and $56^{\text {th }}$ days, respectively). Species richness were exactly the same along the period, except on $35^{\text {th }}$ and $49^{\text {th }}$ days with one additional species at CDS. 

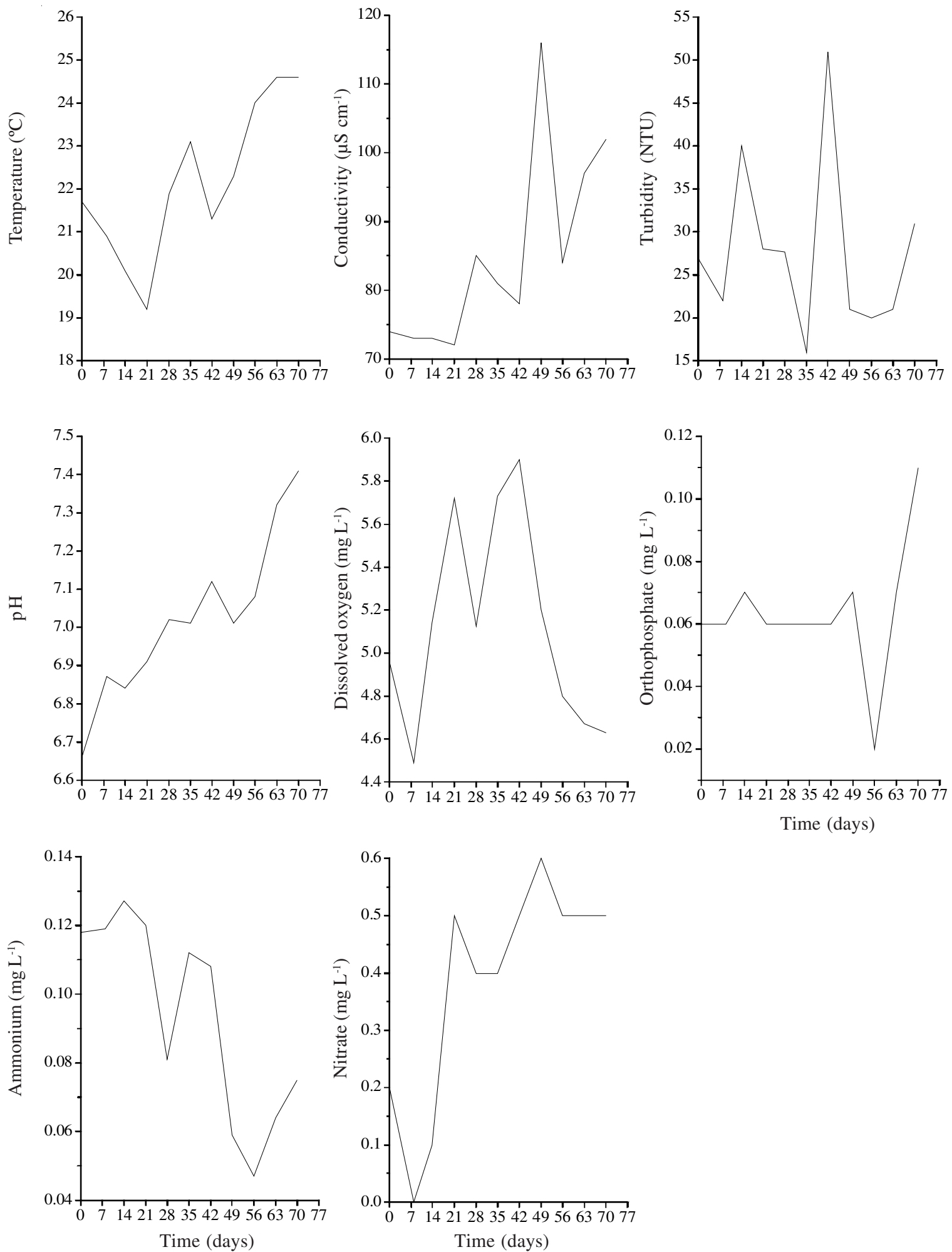

Figure 3. Physical and chemical variables for the whole stream segment during the study period (July 31 to October 10, 2004). 
Chlorophyll $a$ values oscillated throughout the successional period (Fig. 4). Moreover, it was not significantly correlated with any another variable (environmental or biological). In contrast, values of dry weight (Fig. 4) correlated positively with total cover $(\mathrm{r}=0.69, \mathrm{p}<0.05)$. These two biological variables did not correlate with any environmental variable.

Successional dynamics at each stream segment (CDS and PDS) - Oedogonium sp. firstly appeared on the first sampling and reached maximum cover on the $49^{\text {th }}$ day: $40.5 \%$ at CDS and $5.6 \%$ at PDS (Fig. 5). Peak value of cover was higher than that found before disturbance at CDS (29\%). Its percent cover was significantly correlated with time $(r=0.71, p<0.01)$ only at PDS. Cover for this species was positively correlated with total cover $(r=0.83-0.86, p<0.01)$ at both stream segments, but not significantly correlated with any environmental variable. Multiple regression analysis revealed that irradiance and ammonium accounted for $52.1 \%$ of the cover variations of this species at CDS, whereas at PDS temperature, $\mathrm{pH}$ and dissolved oxygen altogether were responsible for $53.8 \%$ of cover variations.

Chaetophora elegans appeared only on the $35^{\text {th }}$ day and reached maximum cover at the end of the period: $2.5 \%$ at CDS and $14.2 \%$ at PDS (Fig. 5). Cover
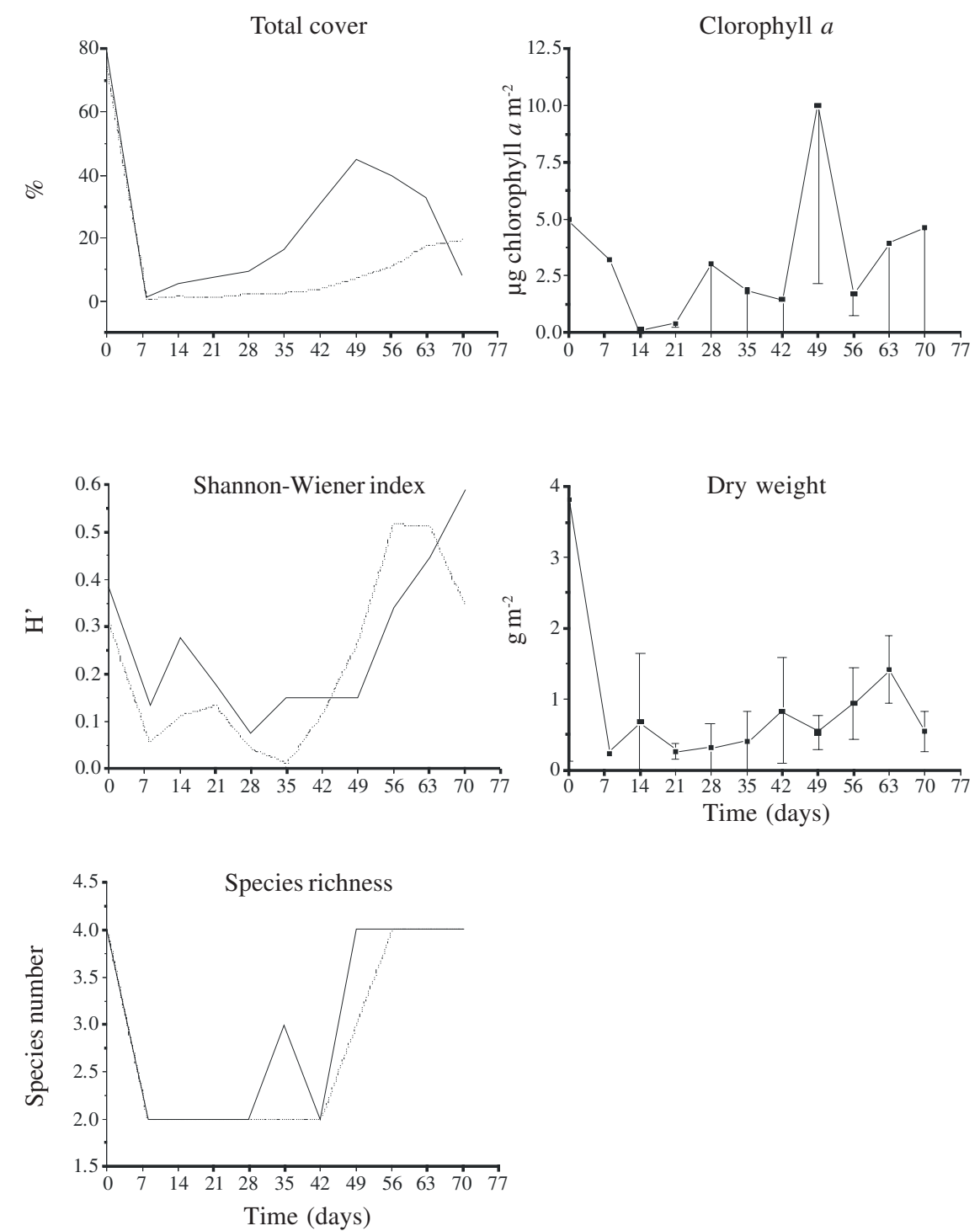

Figure 4. Biological variables during the study period (July 31 to October 10, 2004) for the two experimental segments of the sampling site: completely and partially disturbed. Bars represent one standard-deviation $(n=5)$. ( - - Completely disturbed segment - CDS; ... Partially disturbed segment - PDS). 
was positively correlated with time $(\mathrm{r}=0.76, \mathrm{p}<0.05)$ at both stream segments. There was no significant correlation of cover for this alga with any other biological variables. However, we found positive correlations with temperature $(\mathrm{r}=0.74-0.76, \mathrm{p}<0.05)$ and $\mathrm{pH}(\mathrm{r}=0.78$ $0.81, \mathrm{p}<0.05)$ at both stream segments, whereas at PDS additional positive correlations were found of cover with orthophosfate $(\mathrm{r}=0.86, \mathrm{p}<0.01)$ and current velocity $(\mathrm{r}=0.77, \mathrm{p}<0.05)$. Multiple regression showed that temperature and $\mathrm{pH}$ accounted for $70 \%$ of the cover variations of this alga at both stream segments.

Batrachospermum delicatulum appeared only on the $49^{\text {th }}$ day and reached maximum cover on the $63^{\text {th }}$ day: $4.3 \%$ at CDS and $4.6 \%$ at PDS decreasing thereafter (Fig. 5). Cover of this species was positively correlated positively with time $(\mathrm{r}=0.72$ $0.82, \mathrm{p}<0.05)$ and total cover $(\mathrm{r}=0.70-0.82, \mathrm{p}<0.05)$ at both stream segments, whereas at CDS it was also positively correlated with dry weight $(r=0.78$, $\mathrm{p}<0.05$ ). Cover of this species was positively correlated with temperature $(r=0.57, p<0,05)$ only at PDS. Multiple regression revealed that that temperature, ammonium and dissolved oxygen explained $41 \%$ of its cover fluctuations at CDS, whereas at PDS temperature and $\mathrm{pH}$ accounted for for $43.7 \%$ of cover variations.
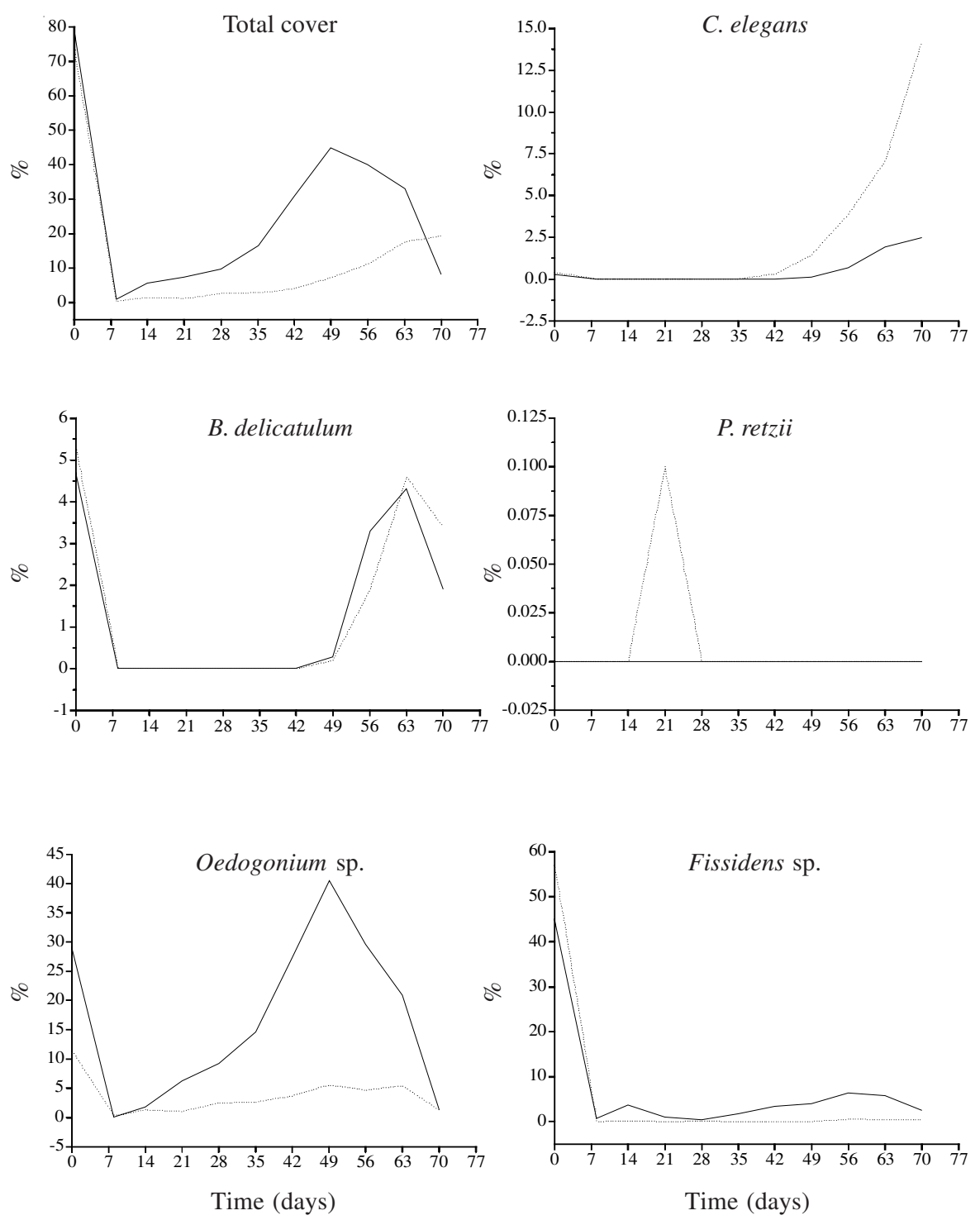

Figure 5. Percent cover (total and average for individual species) during the study period (July 31 to October 10, 2004) at the two experimental segments of the sampling site: completely and partially disturbed. (— - Completely disturbed segment - CDS; ... - Partially disturbed segment - PDS). 
Fissidens sp. firstly appeared on the first sampling and reached maximum cover on the $56^{\text {th }}$ day: $6.7 \%$ at CDS and $0.6 \%$ at PDS (Fig. 5). Cover of this species was positively correlated positively with time $(\mathrm{r}=0.69-0.71, \mathrm{p}<0.05)$ and total cover $(\mathrm{r}=0.83-0.95$, $\mathrm{p}<0.01)$ at both stream segements, whereas at CDS it was also positively correlated with depth $(r=0.60$, $\mathrm{p}<0.05)$. Multiple regression showed that depth and current velocity accounted for $69.5 \%$ of cover fluctuations for this species at CDS, whereas at PDS temperature and $\mathrm{pH}$ accounted for for $54.1 \%$ of cover variations.

ANOVA and Newman-Keuls' test revealed no significant differences $(\mathrm{F}=0.35, \mathrm{p}>0.05)$ among values of percent cover of individual species and total cover at PDS, whereas at CDS similar results were found only for Oedogonium sp. Total cover was not significantly correlated with any environmental variables. Multiple regression revealed that temperature, current velocity and depth accounted for $56.9 \%$ of the variations of total cover at CDS, whereas at PDS $43.7 \%$ of the changes were associated to temperature and $\mathrm{pH}$. Species richness was positively correlated with total cover $(\mathrm{r}=0.64-0.65, \mathrm{p}<0.05)$ and temperature $(\mathrm{r}=0.72-0.77, \mathrm{p}<0.05)$ and negatively with ammonium concentration $(r=-[0.62-0.66], p<0.05)$ at both stream segments. Species richness values were also positively correlated with conductivity $(r=0.64$, $\mathrm{p}<0.05)$ at $\mathrm{CDS}$ and with temperature $(\mathrm{r}=0.72, \mathrm{p}<0.05)$ and dissolved oxygen $(\mathrm{r}=0.59, \mathrm{p}<0.05)$ at PDS. Regression analysis revealed that temperature and conductivity were responsible for $64.1 \%$ of variations of species richness at CDS, whereas at PDS temperature and ammonium accounted for $53,8 \%$ of species richness variations. Shannon-Wiener diversity values were positively correlated with temperature $(\mathrm{r}=0.61, \mathrm{p}<0.05)$ at both stream segments and negatively with ammonium $(\mathrm{r}=-0.71, \mathrm{p}<0.05)$ at PDS. Temperature and dissolved oxygen accounted for $66.2 \%$ of the diversity oscillations at CDS, whereas temperature was responsible for $44.5 \%$ of the oscillations in diversity at PDS.

\section{Discussion}

Among the macroalgal species present during the short-term sucessional process of the study stream: C. elegans and B. delicatulum were classified as later successional species, according to the criteria of McCormick \& Stevenson (1991). Oedogonium sp. was classified as late successional at PDS, whereas at CDS it was considered as indifferent. The fact that all species found at PDS were as late sucessional species, as well as that peak biomass was lower than for the other segment, are good indications of a slower colonization. A possible explanation is that the protection provided by the undisturbed marginal regions around the scraped area supposedly imposed some constraint for algal growth, whereas the naked area at CDS was more favorable for algal colonization.

Considering the model proposed by Biggs et al. (1998) two different life strategies were recognized among the macroalgal species found along the sucession Algae of the first group are generally unicells or filaments, fixed or prostrate and have small to medium-size cells, in addition to the general characteristics of this strategy, i.e. more competitive in stable environments and with intermediary levels of nutrients. Biggs et al. (1998) had classified Oedogonium species as C-S strategists. According to them, communities dominated by taxa with this life strategy vary considerably in the peak biomass values, a characteristic evident in our study, particularly at CDS. They still mentioned that communities dominated by algae as Oedogonium become vulnerable to removal of their filaments due to increasing exposal to water flow in upper layers of the water column. We have also found a similar situation, since the percent cover of this species decreased abruptly after reaching peak biomass at CDS.

Biggs et al. (1998) have classified Batrachospermum species as S strategists. Species classified in this group are predominantly filamentous, with small to mid-size cells with simple to complex branching system. All these characteristics are in concordance with those observed in B. delicatulum in the study site (Necchi Jr. \& Branco 1999). In addition, $\mathrm{S}$ strategists have also low growth rates and low biomass peaks, both evidenced in this study, considering the species classification as late strategist and the relatively low values of biomass peak. Chaetophora species have not been considered by Biggs et al. (1998), but they fit within the characteristics of S strategists, due to their slow growth rates (late successional species) and low biomass peak. Besides, they mentioned that species of this group (e.g. Calothrix and Tolypothrix) can have a mucilaginous sheath, also in agreement with the mucilaginous matrix occurring in this species. In addition, such characteristics agree with those observed in a seasonal study in the study site (Branco \& Necchi Jr. 2003). According to Biggs (1996) the main factors that 
controls the patterns of periphyton biomass and community composition of unshaded regions are disturbance (mostly water flow increase) and resource supply (mostly inorganic nutrients). The differences in community recovery among CDS and PDS can be explained by microhabitat differences, assuming no differences in nutrient supply (once water flowing through both experimental stream segments were relatively homogeneous) and current velocity (not significantly different between stream segments). After complete macroalgal removal at CDS a large free area was available for colonization. Inside this area no sheltered microhabitats occurred, and pioneer species should have fast growth and good fixation capacity. Oedogonium sp. fits within such characteristics, which had an exponential growth at early stage. Peterson \& Stevenson (1991) suggested that the floating and cohesive filaments of green algae (Zygnemales) decrease the effects caused by a disturbance event (water flow increase) and can, at least partially, protect the substratum from total removal. Accordingly, we suppose that the high initial increase in Oedogonium favored the colonization of slower growth species, as we found that growth of C. elegans and B. delicatulum have increased only at later stage.

The flow patterns of PDS was certainly different from that of CDS, although there was no significant differences in the values of current velocity for both segments. In aquatic ecosystems, microtopographic features offer refuges against current and create localized turbulences (Davis \& Barmuta 1989). Thus, regions near the sampling unit edges at PDS had smaller current velocities that would favor the growth of $B$. delicatulum and $C$. elegans due to a stress decrease caused by this physical variable. Accordingly, these two species (with slow growth and growing towards the center) were most abundant at PDS than at CDS. The narrower changes in current velocity at PDS would be an additional factor that contributed for $\mathrm{S}$ strategists success in this segment.

Temperature seems to have played an important role to the sucessional process under this study conditions. For most species and biological variables we found that temperature was one of the most influential variables. Temperature is directly related with the organism metabolism increase and, in our experiment, it was positively correlated with time. Asaeda \& Son (2001) stated that the reproduction rate was directly related to temperature and resource supply in their periphyton modeling study. On the basis of this evidence, we suppose that reproduction rate probably increased following a temperature increase along the successional period. McCormick \& Stevenson (1991) concluded that allogenic factors, such as temperature, can regulate the succession of benthic algae, which corroborates results of this study.

Regarding the community recovery before and at the end of succession, we found that recovery was complete for species richness, but not for the other biological variables. A higher recovery would be expected in experiments during longer periods. In general, the community did not reestablish completely, what rejects (at least partially) the initial hypothesis. On the other hand, the monitoring of the short-term sucessional dynamics was shown to be important for description of some relevant aspects of community characteristics, after disturbance events of variable intensities (moderate and strong), such as: recolonization process, species life strategies and most influential factors for succession.

Succession in lotic ecosystems is considered to be a stochastic event (Fisher 1983; Lake 2000), i.e. biotic changes would not follow a predictable model based on the assumption that colonization and biotic changes are occasional not allowing the construction of theoretical models, particularly on a long-term basis. On the other hand, succession is a deterministic process, since interspecific difference sin the life cycle and autogenic changes in lotic environments result in predictable changes in community structure with time (McCormick \& Stevenson 1991), particularly in short intervals. Our short-term study is consistent with the later statement, since the successional process followed a defined pattern of species richness and abundance, as well as growth forms and life strategies and, thus, may be interpreted as predictable.

Some trends found in this study were essentially similar to those described by Branco et al. (2005): early successional stages were dominated by unbranched filamentous forms, whereas in later stages gelatinous forms were dominant; short-term successional dynamics can be predictable (i.e. deterministic), providing that not unexpected environmental events occur. We agree with those authors in that more studies are required on benthic algae succession dynamics in lotic ecosystems, particularly in tropical regions. The most relevant approaches in future studies should preferably focus on refuge analysis, form-functional relationships and patchy distribution in short and long term intervals to provide information to construct a theoretical framework to explain algal succession dynamics in lotic ecosystems. 


\section{Acknowledgements}

This investigation was supported by a FAPESP (Fundação de Amparo à Pesquisa do Estado de São Paulo) M.Sc. scholarship (02/12476-5) to the senior author. We thank Maria Helena Carabolante for the help in laboratory analyses.

\section{References}

American Public Health Association (APHA) 1992. Standard methods for the examination of water and waste water, $\mathbf{1 8}^{\text {th }}$ edition. Washington, American Public Health Association.

Asaeda, T. \& Son D.H. 2001. A model of the development of a periphyton community: resource and flow dynamics. Ecological modelling 137: 61-75.

Biggs, B.J. 1996. Patterns in benthic algae of streams. Pp. 31-56. In: R.J. Stevenson; M.L. Bothwell \& R.L. Lowe (eds.). Algal ecology: Freshwather Benthic Ecosystems. San Diego, Academic Press.

Biggs, B.J.F.; Stevenson, R.J. \& Lowe, R.L. 1998. A habitat matrix conceptual model for stream periphyton. Archiv für Hydrobiologie 143: 21-56.

Branco, C.C.Z.; Branco, L.H.Z.; Moura, M.O. \& Bertusso, F.R. 2005. The succession dynamics of a macroalgal community after a flood disturbance in a tropical stream from Sno Paulo State, southeastern Brazil. Revista Brasileira de Botânica 28: 267-275.

Branco, C.C.Z. \& Necchi Jr., O. 2003. Temporal dynamics of two species of Chaetophoraceae (Chlorophyta) in tropical streams of Sno Paulo State, souteastern Brazil. Revista Brasileira de Botânica 26: 151-161.

Branco, L.H.Z. \& Necchi Jr., O. 1997. Seasonality of macroalgae in three tropical drainage basins in Sno Paulo State, southeastern Brazil. Archiv für Hydrobiologie 141: 75-91.

Connell, J.H. \& Slatyer, R.O. 1977. Mechanisms of succession in natural comunities and their role in community stability and organization. American Naturalist 111: 1119-1144.

Davis, J.A. \& Barmuta, L.A. 1989. An ecologically useful classification of mean and near-bed flows in streams and rivers. Freshwater Biology 21: 271-282.

Dawson, F.H.; Castellano, E. \& Ladle, M. 1978. Concept of species succession in relation to river vegetation and management. Verhandlungen der Internationalen Vereinigung für Theoretische und Angewandte Limnologie 20: 1429-1434.

Dudley, T.L. \& D'Antonio, C.M. 1991. The effects of substrate texture, grazig, and disturbance on macroalgal establishment in streams. Ecology 72: 297-309.

Egler, F.E. 1954. Vegetation science concepts. I. Initial floristic composition, a factor in old field vegetational development. Vegetatio 4: 412-417.
Fisher, S.G. 1983. Succession in streams. Pp. 7-27. In: J.R. Barnes \& G.W. Minshall (eds.). Stream ecology: application and testing of general ecological theory. New York, Plenum Press.

Grime, J.P. 1977. Evidence for the existense or three primary strategies in plants and its relevance to ecological and evolutionary theory. American Naturalist 111: 1169-1194.

Grime, J.P. 1979. Plants strategies and vegetation processes. New York, John Wiley and Sons.

Huston, M.A. 1979. A general hypothesis of species diversity. American Naturalist 113: 81-101.

Huston, M.A. 1994. Biological Diversity: the coexistence of species on changing landscapes. Cambridge, Cambridge University Press.

Krebs, C.J. 1989. Ecological methodology. New York, Harper \& Row.

Lake, P.S. 2000. Disturbance, patchiness and diversity in streams. Journal of the North American Benthological Society 19: 573-592.

McCormick, P.V. \& Stevenson, R.J. 1991. Mechanisms of benthic algal succession in lotic environments. Ecology 72: $1835-1848$.

McIntosh, R.P. 1974. Plant ecology 1947-1972. In 25 years of Botany, 1947-1972. Annals of Missouri Botanical Garden 61: 132-165.

Necchi Jr., O. 1997. Microhabitat and plant struture of Batrachospermum (Batrachospermales, Rhodophyta) populations in four streams of São Paulo State, southeastern Brazil. Phycological Research 45: 39-45.

Necchi Jr., O. 2004. Amostragem de macroalgas bentônicas. Pp. 167-177. In: C.E.M. Bicudo \& D.C. Bicudo (eds.). Amostragem em Limnologia. São Carlos, Ed. RiMa.

Necchi Jr., O. \& Branco, C.C.Z. 1999. Phenology of a dioecious population of Batrachospermum delicatulum (Batrachospermales, Rhodophyta) in a stream from southeastern Brazil. Phycological Research 47: 251-256.

Necchi Jr., O.; Branco, L.H.Z. \& Branco, C.C.Z. 1995. Comparison of three techniques for estimating periphyton abundance in bedrock streams. Archiv für Hydrobiologie 134: 393-402.

Necchi Jr., O. \& Pascoaloto, D. 1993. Seasonal dynamics of macroalgal communities in the Preto River basin, Sno Paulo, southeastern Brazil. Archiv für Hydrobiologie 129: $231-252$.

Peterson, C.G. \& Stevenson, R.J. 1992. Resistence and resilience of lotic algal communities: importance of disturbance timing and current. Ecology 73: 1445-1461.

Pickett, S.T.A.; Collins, S.L. \& Armesto J.J. 1987. Models, mechanisms and pathways of succession. The Botanical Review 53: 335-371.

Steinman, A.D.; Mulholland, P. J., Palumbo, A.V., Flum, T.F. \& DeAngelis D.L. 1991. Resiliense of lotic lotic ecossitems to a light-elimination disturbance. Ecology 72: 1299-1313.

Zar, J.H. 1999. Biostatistical analysis. $4^{\text {th }}$ ed. New Jersey, Prentice Hall. 